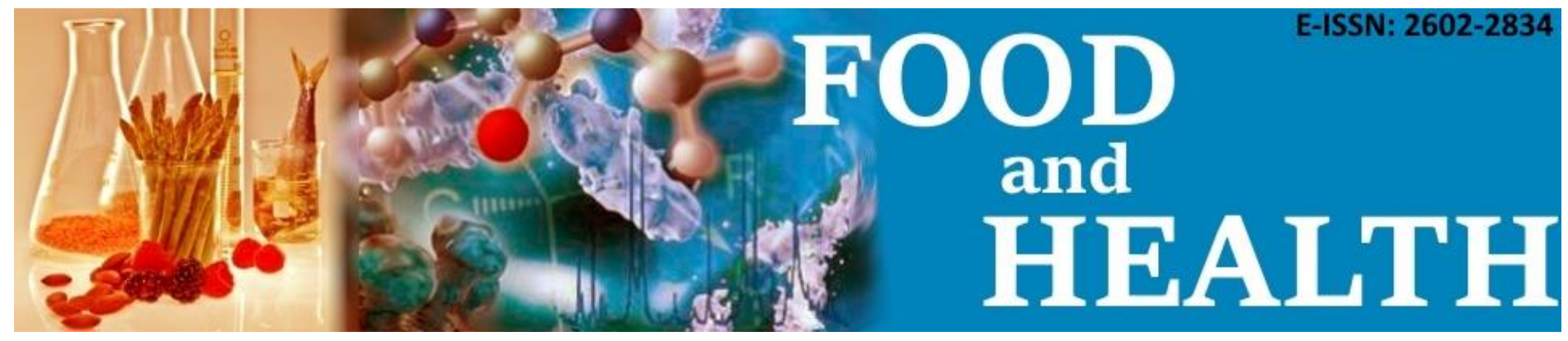

\title{
WHAT DO THEY KNOW ABOUT FOOD SAFETY? A QUESTIONNAIRE SURVEY ON FOOD SAFETY KNOWLEDGE OF KITCHEN EMPLOYEES IN ISTANBUL
}

\author{
Beyza Hatice Ulusoy ${ }^{1} \stackrel{\text { idi }}{\text { id }}$, Nurdan Çolakoğlu ${ }^{2}$ id
}

\section{Cite this article as:}

Ulusoy, B.H., Çolakoğlu, N. (2018). What Do They Know About Food Safety? A Questionnaire Survey on Food Safety Knowledge of Kitchen Employees in Istanbul. Food and Health, 4(4), 283-292. DOI: 10.3153/FH18028

\section{${ }^{1}$ Near East University, Faculty of Veterinary Medicine Food Hygiene and technology Department, Nicosia, Cyprus \\ ${ }^{2}$ Istanbul Arel University, Faculty of Economic and Administrative Sciences, Istanbul, Turkey}

Submitted: 29.11 .2017

Accepted: 05.03.2018

Published online: 01.06.2018

Correspondence:

Beyza ULUSOY

E-mail: beyza.ulusoy@neu.edu.tr

@Copyright 2018 by ScientificWebJournals

Available online at http://jfhs.scientificwebjournals.com

\begin{abstract}
Lack of hygiene knowledge and perception of food handlers, play a big role in outbreaks. The purpose of this study was to evaluate knowledge and awareness of food handlers with regard to food safety in Istanbul. The survey was conducted involving 400 kitchen employees working in 22 kitchens in Istanbul. The findings have been analysed with respect to gender, educational level and work experience variables in the SPSS program. According to results; $90.8 \%$ of participants know that, food hygiene means to remove the illness-causing factors in food. It was determined that the level of knowledge of food handlers did not differ according to gender. According to the hypothesis that we obtained that there is a difference according to education levels. Also, knowledge of the food handlers was significantly different according to the job position and to the duration of the food handler in a food establishment.
\end{abstract}

Keywords: Food safety, Knowledge, Awareness, Food hygiene 


\section{Introduction}

Food borne diseases still continue to be a major public health concern all over the world even in developed countries (Cates et al., 2009). Each year, it is reported that millions of people suffer from food-borne diseases because of consumption contaminated food (Sanlier, 2009; Cates et al., 2009; Senior, 2009). According to European Food Safety Authority (EFSA, 2010) report, $48.7 \%$ of foods borne illnesses are associated with food services. Consumers, become more concerned with food safety and quality of food ingredients because of the outbreaks caused by food borne disease agents. European Food Safety Authority and the European Centrefor Disease Prevention and Control reported that, only in the year of 2013, 5196 food-borne and waterborne outbreaks, 5946 hospitalizations and 11 deaths in the European Union (EU). Among these, 22.2\% of out breaks were occurred in food establishments such as restaurants, cafes, pubs, bars and hotels (EFSA \& ECDC, 2015).

News about the disease outbreaks, lectures on food safety in schools, reports and announcements from authority cause consumers to have awareness and knowledge on food borne diseases. In such a case, consumer awareness, hazard possibility coming from foods and quality searching, make food handlers to obey hygiene rules and to take care what they do. A study in USA, suggested that improper food handler practices contributed to approximately $97 \%$ of food borne illnesses (Howeset al., 1996). As Sharif \& Al-Malki (2010) reported; three factors are playing important role in food poisoning outbreaks concerning food handlers: knowledge, attitude and the other one is practice. Several authors have identified that good levels of knowledge on food safety among food handlers and the effective application of such knowledge in food handling practices are essential in ensuring the production of safe food (Mortlock, Peters, \& Griffith, 1999). As Todd et al. (2007) mentioned, the most reported cases related to food-borne disease are because of inadequate temperature control, infected food handlers and bare hand food manipulation, contaminated raw ingredients, cross-contamination and inadequate heat processing. In order to prevent these errors, food handlers' knowledge and awareness is surely very important. Because of that we examined food handlers' knowledge on such subjects. In the study performed by Smigic et al. (2016), food handlers' knowledge and gaps related to these critical food safety issues were investigated. On the other hand, they also investigated and compared the level of food safety knowledge among food handlers in three different countries, Serbia, Greece and Portugal. In the study, the knowledge score (KS) was calculated by dividing the sum of correct answers by the total number of questions. As the conclusion of this research; the average KS for all participants was $70.5 \%$. The best KS was obtained for Portuguese food handlers (72.6\%), then Serbian food handlers $(71.3 \%)$ and Greek food handlers get lower scores (69.1\%). Pichler et al. (2014) was planned a study to detect the most important gaps in knowledge on food safety among food handlers in Vienna, Austria. According the results of this study; the average knowledge score for all food handlers was $76 \%$. Knowledge gaps that determined in this research were concerning correct temperatures for cooking, holding and storing foods. There are many studies about the knowledge and practices of food safety which was done in different types of food processing plants and variety of food handlers (Bolton et al., 2008; Dewaal, 2003; Howells et al., 2008; McCarthy et al., 2007; Gomes-Neves et al., 2007; Marais, Conradie \& Labadarios, 2007; Sanlier, 2009; Tokuç et al., 2009; Walker, Pritchard, \& Stephen, 2003; Giritlioglu, Batman \&Tetik et al., 2011).

Food handlers' training is seen as an important strategy to increase the knowledge and awareness. As Clayton et al. (2002) reported; if food handlers develop a correct perception of hygiene, it will be possible to accomplish the risk of food borne illnesses. On the other hand, a number of studies indicate that although training may increase the knowledge of food safety, it does not always result in a positive change in food handling behaviours (Howes et al. 1996).

As Bas et al. (2006) mentioned, there are many facts imposing risk on food safety in Turkish food and beverage industry, due to industrialization and mass production, fast food consumption, street vendors and growing international trade. Turkish Food Hygiene Regulation (Anonymous, 2011) notified many hygiene rules that food industry should obey in order to obtain healthy and safety food. On the other hand, according to this regulation, Turkish food business must provide food hygiene trainings related with work activities of their staff.

Many researchers concluded that safe food is the most important subject of the day and strictly related with good hygiene practices and the knowledge of the employees that carry the food production process. With the idea we got from this truth, we aimed to evaluate knowledge and awareness of all employees on food safety and hygiene rules and personal hygiene that hugs all food safety practices, in all types of kitchens, with a large scale in district of Istanbul. Also we focused on what they don't know about safe food. We tried to contact with food handlers working at all stages 
in caterings, restaurants, hotels, kebab houses, school kitchens. The results of this study will provide information for the national food safety training strategy.

\section{Materials and Methods}

\section{Questionnaire Design}

In order to determine the perception of hygiene and food safety knowledge of kitchen employees, a self-administrable, Likert type questionnaire has been used. The questionnaire was prepared based on the previous study conducted by Çakıroğlu and Uçar (2008) and the questions were developed with the help of literature review on food safety and food quality. The questionnaire consisted of 38 statements in three groups. The groups are about; socio-demographic characteristics (7 questions), food safety and hygiene rules (17 statements) and personal hygiene (12 statements). The questionnaire includes a set of negative sentences in addition to the positive ones. Responses to the positive sentences have been graded as follows: 'I certainly agree', 5 points; 'I agree', 4 points; 'undecided', 3 points; I don't agree', 2 points and 'I certainly don't agree', 1 point. In the negative sentences, the grades have been assigned in a reverse order.

\section{Participating the Business and Delivery of the Questionnaires}

This survey was conducted from March to December involving 400 kitchen employees working in 22 kitchens in Istanbul, a city in Turkey. Medium and large scaled enterprises' kitchens which includes at least 10 food handlers, were selected for the survey.Assessments were comprised of catering establishments, school food services, hotels, kebab houses, and restaurants. The employees in the selected kitchens were asked to complete self-administrable questionnaire in order to collect research data.

\section{Evaluating the Questionnaires}

The findings have been analyzed with respect to gender, educational level and work experience variables in the Statistical Package for Social Sciences (SPSS) program. In evaluating the hygiene perception grades, "Independent-samples $T$ test" for the gender variable, "One-way Anova" analysis and "scheffe test" for the other variables have been applied. Frequencies, averages and standard deviations have been calculated.

\section{Results and Discussion}

The demographic characteristics of 400 persons who participated in the survey are given in Table 1 . When Table 1 is examined, it was seen that $76 \%$ of the participants in food businesses were male workers, $75.8 \%$ were in the age range of $19-40,42.2 \%$ were high school graduates, $26.5 \%$ were journeyman and $34.8 \%$ of the participants were working in a food service for more than 10 years. $64.8 \%$ of them were educated on food safety and $77 \%$ of them had periodic controls in their institution.

Table1. The demographic characteristics of participants

\begin{tabular}{|c|c|c|}
\hline & $\mathrm{f}$ & $\%$ \\
\hline \multicolumn{3}{|l|}{ Gender } \\
\hline Female & 96 & 24 \\
\hline Male & 304 & 76 \\
\hline \multicolumn{3}{|l|}{ Age } \\
\hline$<18$ & 19 & 4.8 \\
\hline $19-40$ & 303 & 75.8 \\
\hline $41-60$ & 74 & 18.4 \\
\hline$>60$ & 4 & 1 \\
\hline \multicolumn{3}{|l|}{ Education } \\
\hline Primary school & 163 & 40.8 \\
\hline High school & 169 & 42.2 \\
\hline University & 66 & 16.5 \\
\hline Master & 2 & 0.5 \\
\hline \multicolumn{3}{|l|}{ Position of work } \\
\hline Executive chef & 45 & 11.2 \\
\hline Sous chef & 57 & 14.3 \\
\hline Chef de party & 81 & 20.2 \\
\hline Journeyman & 106 & 26.5 \\
\hline Busboy & 72 & 18 \\
\hline Steward & 39 & 9.8 \\
\hline \multicolumn{3}{|c|}{ Years in food service } \\
\hline$<$ 1year & 55 & 13.8 \\
\hline $1-5$ years & 124 & 31 \\
\hline $6-10$ years & 82 & 20.4 \\
\hline$>10$ years & 139 & 34.8 \\
\hline \multicolumn{3}{|c|}{ Education on food safety } \\
\hline Yes & 259 & 64.8 \\
\hline No & 141 & 35.2 \\
\hline \multicolumn{3}{|l|}{ Periodic controls } \\
\hline Yes & 308 & 77.0 \\
\hline No & 81 & 20.3 \\
\hline No answer & 11 & 2.7 \\
\hline
\end{tabular}

The answers to the statements that measure the knowledge and awareness of food safety and hygiene rules that must be observed in food enterprises are as shown in Table 2. The reliability analysis of the statements on food safety and hygiene rules was examined with the Cronbach alpha test and the value found to be 0,85 . According to this value, it can be said that the answers given to the questions are consistent and the questions are reliable. When the results of this table are evaluated, some important points can be expressed as follows: $90.8 \%$ of participants know that, food hygiene means to remove the illness-causing factors in food. 5\% of participants didn't agree this statement. This result shows that they mostly know food hygiene is needed for healthy 
food but on the other hand there are still food handlers that do not know neither what food hygiene means. Giritlioglu at al. (2011) performed a questionnaire survey to assess the knowledge and practice of food safety and hygiene of 82 students in university cookery programs in Turkey. The results showed that although the students regarded the issues of food safety and personal hygiene as important, they had inadequate knowledge in these areas. Totally $17 \%$ of participants commented as I certainly don't agree, I don't agree and undecided for "Bacteria can be transmitted to food via poorly cleaned equipment" statement and as seen with this result there is a lack of information about this subject. Also this result is similar with the answers for another statement; "Hot served foods should be kept at $60^{\circ} \mathrm{C}$ or above, cold served foods should be kept at $4{ }^{\circ} \mathrm{C}$ and below". The proportion of those who answered "There is no harm in keeping animal originated food such as meat, milk, eggs at room temperature" is quite high with $16.5 \%$. Participants answered as I certainly don't agree, I don't agree and undecided for the statement "Water used for every business in the kitchen should be drinkable" at the ratio of $16.2 \%$. most of the participants $(83.8 \%)$ had no information that drinkable water is needed in kitchen for any purpose although this situation is underlined in Turkish Food Hygiene Regulation (Anonymous, 2011). 36\% of participants answered as I certainly don't agree, I don't agree and undecided for the statement "Cooked foods can be kept at room temperature for more than 2 hours before serving". In addition, 18 people $(4.5 \%)$ left this question blank. $23.3 \%$ of the kitchen workers responded by saying "Frozen foods can be frozen again after thawed", undecided, agree and strongly agree. The phrase "Frozen foods can be thawed at room temperature" was answered as undecided, I agree and I strongly agree at the ratio of $54.2 \%$ and was left blank at the ratio of $5.8 \%$. About more than half of food handlers have false knowledge on safety of frozen foods. The answers that were given to statements on frozen foods also indicated that there is a lack of knowledge on frozen foods. Foods should never be defrosted in this way why the reason bacteria can multiply rapidly between $4-60{ }^{\circ} \mathrm{C}$. In the study of Al-Shabib, Mosilhey $\&$ Husain (2016), 85\% of workers were aware about the fact that defrosted foods cannot be refrozen again. According to Sani \&Siow (2014), about $75 \%$ of the respondents had knowledge about refreezing defrosted food. "I agree, I strongly agree and undecided" answers were given to "There is no harm in terms of human health for some of the molds growing on the food" is at the ratio of $30.2 \%$. This is a big ratio for not to have knowledge about health harms caused by mycotoxins of moulds.
The reliability analysis of the statements on knowledge and awareness of personal hygiene was examined with the Cronbach alpha test and the value found to be 0.79 . According to this value, it can be said that the answers given to the questions are consistent and the questions are reliable. The answers to the statements that measure the knowledge and awareness of personal hygiene are as shown in Table 3. When the results of this table are evaluated, some important points can be expressed as follows:

The percentage of those who are certainly agree, agree and undecided with the phrase "Kitchen worker who is directly related to the food can touch the food with his bare hand" is quite high with $38.7 \%$. Totally $29 \%$ of participants commented as I certainly don't agree, I don't agree and undecided for "In our nose there are bacteria which can cause food poisoning". Food intoxication by Staphylococcus aureus is considered as the third most important cause of food borne diseases in the world (Normanno et al., 2005) and this bacterium can be presence in nose microflora. The reason for asking respondents' idea about this was to understand if they know about this pathogen. In a similar study performed by N.A. Al-Shabib, Mosilhey \& Husain (2016), $52.9 \%$ of respondents knew $S$. aureus as a food pathogen. $27.4 \%$ of participants certainly didn't agree, didn't agree and had no decision if it is also needed to wash their hands except of washing just before starting work. $21 \%$ of the food handlers that participated to our survey don't know that open wounds and abscess can be sources for bacteria causing food poisoning. Similar to this result, $22.8 \%$ of participants certainly didn't agree, didn't agree and had no decision if they have to start to work after they have closed their wounds with waterproof tape. The rate of kitchen workers, who think that food handlers suffering from flu, diarrhea, influenza or other illnesses, may work in the kitchen, is $15.5 \% .84 .5 \%$ of respondents knew that this is not appropriate. This result is concordant with Codex Alimentarius Commission (2003) report. According to that it is stated that sick food handlers are not allowed to work or deal with foods. In the study of Al-Shabib, Mosilhey \& Husain (2016), 29-31 \% of workers handle foodstuffs when sick or having wounds and cuts. This percentage evaluated by the researchers as not very high. Food handlers also don't know that each kitchen worker is a tool for the transportation of bacteria to food $(17.5 \%)$, they have to remove their rings, watches, bracelets before starting work (15.8\%) and must not smoke (14.3\%). As Abdul-Mutalib et al. (2012) reported, more than $40 \%$ of their respondents wear jewellery while working. High percentage $(86.2 \%)$ of food handlers was also aware of wearing watches, earrings and rings in the study of Al-Shabib, 
Mosilhey\& Husain (2016). This result shows similarity with our result.

Table 2. Answers to food safety and hygiene rules knowledge and awareness statements

\begin{tabular}{|c|c|c|c|c|c|c|c|c|c|c|c|c|}
\hline \multirow[b]{2}{*}{ Statements } & \multicolumn{2}{|c|}{\begin{tabular}{|c|} 
I certainly \\
don't \\
agree
\end{tabular}} & \multicolumn{2}{|c|}{$\begin{array}{l}\text { I don't } \\
\text { agree }\end{array}$} & \multicolumn{2}{|c|}{ Undecided } & \multicolumn{2}{|c|}{ I agree } & \multicolumn{2}{|c|}{$\begin{array}{c}\text { I certainly } \\
\text { agree }\end{array}$} & \multicolumn{2}{|c|}{ No answer } \\
\hline & $\mathrm{f}$ & $\%$ & $\mathrm{f}$ & $\%$ & $\mathrm{f}$ & $\%$ & $\mathrm{f}$ & $\%$ & $\mathrm{f}$ & $\%$ & $\mathrm{f}$ & $\%$ \\
\hline $\begin{array}{l}\text { Food hygiene means to remove the illness-causing factors } \\
\text { in food }\end{array}$ & 7 & 1.8 & 13 & 3.2 & 17 & 4.2 & 116 & 29 & 247 & 61.8 & - & \\
\hline $\begin{array}{l}\text { There is no inconvenience that the waste materials are kept } \\
\text { in the kitchen together with the foodstuffs }\end{array}$ & 221 & 55.3 & 85 & 21.3 & 25 & 6.2 & 28 & 7 & 30 & 7.4 & 11 & 2.8 \\
\hline $\begin{array}{l}\text { Cooked and uncooked foods should be prepared with sep- } \\
\text { arate equipment and should be stored separately }\end{array}$ & 9 & 2.2 & 19 & 4.8 & 32 & 8 & 102 & 25.5 & 230 & 57.5 & 8 & 2 \\
\hline $\begin{array}{l}\text { Bacteria can also be transmitted to food via poorly cleaned } \\
\text { equipment }\end{array}$ & 18 & 4.5 & 27 & 6.8 & 23 & 5.7 & 108 & 27 & 224 & 56 & - & \\
\hline $\begin{array}{l}\text { The case of food poisoning caused by a meal prepared in } \\
\text { your company causes damage to the company's reputation }\end{array}$ & 15 & 3.8 & 12 & 3 & 27 & 6.7 & 71 & 17.7 & 275 & 68.8 & - & \\
\hline $\begin{array}{l}\text { Hot served foods should be kept at } 60^{\circ} \mathrm{C} \text { or above, cold } \\
\text { served foods should be kept at } 4{ }^{\circ} \mathrm{C} \text { and below }\end{array}$ & 8 & 2 & 15 & 3.7 & 51 & 12.8 & 107 & 26.8 & 212 & 53 & 7 & 1.7 \\
\hline $\begin{array}{l}\text { There is no harm in keeping animal originated food such } \\
\text { as meat, milk, eggs at room temperature }\end{array}$ & 183 & 45.8 & 124 & 31 & 24 & 6 & 37 & 9.2 & 25 & 6.3 & 7 & 1.7 \\
\hline $\begin{array}{l}\text { Be sure that the meats that are accepted to the establish- } \\
\text { ment are brought to operation under the cold chain }\end{array}$ & 8 & 2 & 14 & 3.5 & 33 & 8.2 & 103 & 25.8 & 232 & 58 & 10 & 2.5 \\
\hline $\begin{array}{l}\text { Sufficient number of showers and washbasins must be } \\
\text { available in the food facility according to the density of the } \\
\text { staff }\end{array}$ & 11 & 2.8 & 8 & 2 & 19 & 4.7 & 107 & 26.8 & 245 & 61.2 & 10 & 2.5 \\
\hline $\begin{array}{l}\text { The water used for every work in the kitchen must be } \\
\text { drinkable }\end{array}$ & 13 & 3.2 & 13 & 3.2 & 39 & 9.8 & 94 & 23.5 & 233 & 58.3 & 8 & 2 \\
\hline $\begin{array}{l}\text { Bacteria multiply very quickly in the foods that are kept } \\
\text { at room temperature and reach the level that can cause food } \\
\text { poisoning }\end{array}$ & 15 & 3.7 & 12 & 3 & 17 & 4.2 & 103 & 25.8 & 242 & 60.5 & 11 & 2.8 \\
\hline $\begin{array}{l}\text { Cooked foods can be kept at room temperature for more } \\
\text { than } 2 \text { hours before serving }\end{array}$ & 120 & 30 & 118 & 29.5 & 43 & 10.8 & 50 & 12.5 & 51 & 12.7 & 18 & 4.5 \\
\hline Frozen foods can be frozen again after thawed & 208 & 52 & 81 & 20.2 & 28 & 1 & 32 & 8 & 33 & 8.3 & 18 & 4.5 \\
\hline $\begin{array}{l}\text { Typhoid fever is an important digestive system disease and } \\
\text { may infect people by consuming chicken, milk, eggs }\end{array}$ & 25 & 6.3 & 28 & 7 & 78 & 19.5 & 122 & 30.5 & 114 & 28.5 & 33 & 8.2 \\
\hline Frozen foods can be thawed at room temperature & 102 & 25.5 & 58 & 14.5 & 33 & 8.2 & 92 & 23 & 92 & 23 & 23 & 5.8 \\
\hline $\begin{array}{l}\text { The most important signs in food poisoning are; diarrhoea, } \\
\text { nausea, vomiting, fever, abdominal pain, fatigue and loss } \\
\text { of appetite }\end{array}$ & 11 & 2.8 & 2 & 0.5 & 18 & 4.5 & 112 & 28 & 138 & 59.5 & 19 & 4.7 \\
\hline $\begin{array}{l}\text { There is no harm in terms of human health for some of the } \\
\text { moulds growing on the food }\end{array}$ & 195 & 48.8 & 61 & 15.2 & 37 & 9.2 & 50 & 12.5 & 34 & 8.5 & 23 & 5.8 \\
\hline
\end{tabular}


Table 3. Answers to personal hygiene knowledge and awareness statements

\begin{tabular}{|c|c|c|c|c|c|c|c|c|c|c|c|c|}
\hline \multirow[b]{2}{*}{ Statements } & \multicolumn{2}{|c|}{\begin{tabular}{|c|} 
I certainly \\
don't \\
agree
\end{tabular}} & \multicolumn{2}{|c|}{$\begin{array}{l}\text { I don't } \\
\text { agree }\end{array}$} & \multicolumn{2}{|c|}{ Undecided } & \multicolumn{2}{|c|}{ I agree } & \multicolumn{2}{|c|}{$\begin{array}{c}\text { I certainly } \\
\text { agree }\end{array}$} & \multicolumn{2}{|c|}{ No answer } \\
\hline & $\mathrm{f}$ & $\%$ & $\mathrm{f}$ & $\%$ & f & $\%$ & $\mathrm{f}$ & $\%$ & $\mathrm{f}$ & $\%$ & $\mathrm{f}$ & $\%$ \\
\hline $\begin{array}{l}\text { Each kitchen worker is a tool for the transportation of bac- } \\
\text { teria to food }\end{array}$ & 9 & 2.2 & 13 & 3.3 & 48 & 12 & 152 & 38 & 178 & 44.5 & - & \\
\hline $\begin{array}{l}\text { The kitchen worker, who is directly related to the food, can } \\
\text { touch the food with bare hands }\end{array}$ & 138 & 34.5 & 92 & 23 & 41 & 10.2 & 69 & 17.3 & 45 & 11.2 & 15 & 3.8 \\
\hline $\begin{array}{l}\text { In our nose there are bacteria which can cause food poi- } \\
\text { soning }\end{array}$ & 18 & 4.4 & 27 & 6.8 & 71 & 17.8 & 116 & 29 & 157 & 33.2 & 11 & 2.8 \\
\hline $\begin{array}{l}\text { Open wounds and abscess can be sources for bacteria caus- } \\
\text { ing food poisoning }\end{array}$ & 10 & 2.5 & 34 & 8.5 & 40 & 10 & 132 & 33 & 184 & 46 & - & \\
\hline $\begin{array}{l}\text { Kitchen workers must go through health check every } 6 \\
\text { months }\end{array}$ & 10 & 2.5 & 17 & 4.3 & 31 & 7.8 & 87 & 21.7 & 255 & 63.7 & - & \\
\hline $\begin{array}{l}\text { It is enough for the kitchen staff to wash their hands in the } \\
\text { kitchen just before starting work }\end{array}$ & 176 & 44 & 73 & 18.3 & 27 & 6.8 & 55 & 13.7 & 55 & 13.7 & 14 & 3.5 \\
\hline $\begin{array}{l}\text { If the kitchen worker is suffering from flu, diarrhoea, in- } \\
\text { fluenza or other illnesses, there is no problem working in } \\
\text { the kitchen }\end{array}$ & 196 & 49 & 114 & 28.5 & 20 & 5 & 24 & 6 & 38 & 9.5 & 8 & 2 \\
\hline $\begin{array}{l}\text { Appropriate hand washing is made with hot water and by } \\
\text { brushing the nails with soap and disinfectant by rubbing } \\
\text { the hands. }\end{array}$ & 8 & 2 & 7 & 1.7 & 19 & 4.8 & 106 & 26.5 & 251 & 62.8 & 9 & 2.2 \\
\hline $\begin{array}{l}\text { Personnel should show maximum care on hygiene when } \\
\text { entering or leaving food processing areas }\end{array}$ & 14 & 3.5 & 8 & 2 & 22 & 5.5 & 100 & 25 & 238 & 59.5 & 18 & 4.5 \\
\hline $\begin{array}{l}\text { There is no objection to smoking in the food processing } \\
\text { area }\end{array}$ & 246 & 61.5 & 68 & 17 & 21 & 5.2 & 22 & 5.5 & 35 & 8.8 & 8 & 2 \\
\hline $\begin{array}{l}\text { Staff working in food production should start to work after } \\
\text { they have closed their wounds with waterproof tape }\end{array}$ & 29 & 7.2 & 35 & 8.8 & 27 & 6.8 & 137 & 34.2 & 155 & 38.8 & 17 & 4.2 \\
\hline $\begin{array}{l}\text { Employees do not need to remove their rings, watches, } \\
\text { bracelets before starting work }\end{array}$ & 195 & 48.8 & 84 & 21 & 29 & 7.2 & 32 & 8 & 31 & 7.8 & 29 & 7.2 \\
\hline
\end{tabular}

The most often reported food handlers' mistakes were handling of food by an infected person or by a person carries food-borne pathogens, touching the food with bare-hand, improper hand washing and insufficient cleaning of equipment that are in contact with foods (Nørrung \& Buncic, 2008).

The following hypotheses were established to determine whether the knowledge of food handlers on "Food Safety and Hygiene Rules" and "Personal Hygiene" differs according to the socio-demographic characteristics and the results were given in Table 4. The independent samples t test and the ANOVA test were conducted to determine differences in significance level of 0.05 .

When the hypotheses shown in the Table 4 are evaluated; it was determined that the level of knowledge of employees did not differ according to gender (Food Safety and Hygiene Rules knowledge; female $=3.6195 \pm 0.9011$, male $=3.8185$ \pm 0.8891 and Personal Hygiene knowledge; female $=3.9444$ \pm 0.6324 , male $=3.9715 \pm 0.6987$ ). It was seen that the regular audits and inspections of the food establishments and the trainings related to their fields have great importance in increasing the knowledge level of the kitchen workers. As the result of another research, it was observed that food safety training increased knowledge on food safety issues (Lynch, Elledge, Griffith, \& Boatright, 2003). A meta-analysis has shown that food safety training increases knowledge and improves attitudes about hand hygiene practices (Soon, Baines, \& Seaman, 2012). On the other hand, it is important not to forget that more knowledge does not always lead to positive changes in food handling procedures (Bas, Ersun, \&Kıvanç, 2006; Ansari-Lari, Soodbakhsh, \&Lakzadeh, 2010; Park, Kwak, \& Chang, 2010). Along with training, there are many other factors that may affect the knowledge of food handlers, such as age, education or work experience (Pichler, Ziegler, Aldrian, \&Allerberger, 2014). The hypothesis that there is a difference according to education levels in terms of Food Safety and Hygiene Rules knowledge has been tested with One-way Anova and found to be dif- 
ferent. According to the Tukey HSD test; while the education level of high school and primary education was in the same group with the lower average $(3.7000 \pm 0.9535,3.7132$ \pm 0.8941 , respectively); university graduates (4.0848 $\pm 0.6607)$ were included in a separate group. Personal Hygiene knowledge also differs according to education level. As a result of the Tukey HSD test; while the educational status of primary and high school graduates (3.8681 $\pm 0.6817,3.9359 \pm 0.7143$, respectively) were in the same group with lower mean; university graduates (4.2696 $\pm 0.5035)$ were in a separate group. According to the Anova test results; knowledge on Food Safety and Hygiene Rules was different according to the job position. Among the post hoc tests, the Tukey HSD test was conducted and according to the results of stewards and sous chefs $(3.3575 \pm 1.1178$ and $3.6749 \pm 0.8207$, respectively) were in a group, while those who work as busboy, journeyman, chef de party and executive chef $(3.7061 \pm 0.8951,3.8113 \pm 0.8957,3.8954$ $\pm 0.7987,4.0341 \pm 0.8279$, respectively) were found to be in the other group with a higher average. In this case, knowledge of stewards and sous chefs was lower than others. Personal hygiene knowledge of food handlers was also different according to the job position. Tukey HSD test was performed among Post Hoc tests and those who were working in the steward position were separated from the others with the lowest mean $(3.7607 \pm 0.7322)$ alone. Those who worked as sous chef, busboy, journeyman, chef de party and executive chef were in a group $(3.9094 \pm 0.6678,3.9347$ $\pm 0.7068,3.9387 \pm 0.7119,4.0422 \pm 0.6277,4.1870 \pm 0.5986$ respectively). Food Safety and Hygiene Rules knowledge differs according to the duration of the food handler in a food establishment. According to the results of the Tukey HSD test; the ones who worked for 6-10 years (3.8903 $\pm 0.8008)$ and more than 10 years $(4.0479 \pm 0.8008)$ were in same group, while those who worked in one food operation less than 1 year $(3.3412 \pm 1.1097)$ and those who worked for $1-5$ years $(3.5716 \pm 0.9209) 0.7116)$ were in the same group. As the number of working period in food operation increases, the level of knowledge of Food Safety and Hygiene Rules seems to increase. Similar results were obtained for Personal Hygiene knowledge. According to the results of the study performed by R. Garayoa et al. (2011), hygiene knowledge levels were slightly better among people who are graduated from middle- or high-school and for those who had worked 10 or more years in the catering sector.

Table 4. Comparison the knowledge of food handlers according to the socio-demographic characteristics

\begin{tabular}{|c|c|c|c|}
\hline Hypotheses & Test & Result & Decision \\
\hline $\begin{array}{l}\mathrm{H}_{1} \text { : The knowledge on the Food Safety and Hygiene Rules of kitchen workers } \\
\text { differs according to gender }\end{array}$ & $\begin{array}{l}\text { Independent } \\
\text { t Test }\end{array}$ & $\mathrm{t}=-1.905 \mathrm{df}=398 \mathrm{p}=0.057$ & Rejected \\
\hline $\begin{array}{l}\mathrm{H}_{2} \text { : Personal Hygiene knowledge of kitchen workers differs according to gen- } \\
\text { der }\end{array}$ & $\begin{array}{l}\text { Independent } \\
\text { t Test }\end{array}$ & $\mathrm{t}=-0.338 \mathrm{df}=398 \mathrm{p}=0.736$ & Rejected \\
\hline $\begin{array}{l}\mathrm{H}_{3} \text { : The knowledge of kitchen workers on Food Safety and Hygiene Rules } \\
\text { differs according to the their training situation }\end{array}$ & $\begin{array}{l}\text { Independent } \\
\text { t Test }\end{array}$ & $\mathrm{t}=7,428 \mathrm{df}=398 \mathrm{p}=0.000$ & Accepted \\
\hline $\begin{array}{l}\mathrm{H}_{4} \text { : The knowledge of kitchen workers on Personal Hygiene differs according } \\
\text { to their training situation. }\end{array}$ & $\begin{array}{l}\text { Independent } \\
\text { t Test }\end{array}$ & $\mathrm{t}=6.880 \mathrm{df}=398 \mathrm{p}=0.000$ & Accepted \\
\hline $\begin{array}{l}\mathrm{H}_{5} \text { : The knowledge on the Food Safety and Hygiene Rules of the kitchen staff } \\
\text { varies according to whether or not periodic checks are carried out at the in- } \\
\text { stitution where they work }\end{array}$ & $\begin{array}{l}\text { Independent } \\
\mathrm{t} \text { Test }\end{array}$ & $\mathrm{t}=6.979 \mathrm{df}=387 \mathrm{p}=0.000$ & Accepted \\
\hline $\begin{array}{l}\mathrm{H}_{6} \text { : The knowledge onPersonal Hygieneof the kitchen staff varies according } \\
\text { to whether or not periodic checks are carried out at the institution where they } \\
\text { work }\end{array}$ & $\begin{array}{l}\text { Independent } \\
\text { t Test }\end{array}$ & $\mathrm{t}=5.650 \mathrm{df}=387 \mathrm{p}=0.000$ & Accepted \\
\hline $\begin{array}{l}\mathrm{H}_{7} \text { : The knowledge of kitchen workers' on Food Safety and Hygiene Rules } \\
\text { differs according to the educational situation }\end{array}$ & $\begin{array}{l}\text { One way } \\
\text { Anova }\end{array}$ & $F=5.157 \mathrm{df}=2 \mathrm{p}=0.006$ & Accepted \\
\hline $\begin{array}{l}\mathrm{H}_{8} \text { : The knowledge of kitchen workers' on Personal Hygienediffers according } \\
\text { to the educational situation }\end{array}$ & $\begin{array}{l}\text { One way } \\
\text { Anova }\end{array}$ & $\mathrm{F}=8.902 \mathrm{df}=2 \mathrm{p}=0.000$ & Accepted \\
\hline $\begin{array}{l}\mathrm{H}_{9} \text { : The knowledge of kitchen workers' on Food Safety and Hygiene Rules } \\
\text { differs according to the job position of food handler }\end{array}$ & $\begin{array}{l}\text { One way } \\
\text { Anova }\end{array}$ & $\mathrm{F}=3.085 \mathrm{df}=5 \mathrm{p}=0.010$ & Accepted \\
\hline $\begin{array}{l}\mathrm{H}_{10} \text { : The knowledge of kitchen workers' on Personal Hygiene differs accord- } \\
\text { ing to the job position of food handler }\end{array}$ & $\begin{array}{l}\text { Oneway } \\
\text { Anova }\end{array}$ & $\mathrm{F}=2.022 \mathrm{df}=5 \mathrm{p}=0.075$ & Rejected \\
\hline $\begin{array}{l}\mathrm{H}_{11} \text { : The knowledge of kitchen workers' on Food Safety and Hygiene Rules } \\
\text { differs according to their professional experience (the working time of the } \\
\text { food business) }\end{array}$ & $\begin{array}{l}\text { One way } \\
\text { Anova }\end{array}$ & $\mathrm{F}=12.139 \mathrm{df}=3 \mathrm{p}=0.000$ & Accepted \\
\hline $\begin{array}{l}\mathrm{H}_{12} \text { : The knowledge of kitchen workers' on Personal Hygiene differs accord- } \\
\text { ing to their professional experience (the working time of the food business) }\end{array}$ & $\begin{array}{l}\text { One way } \\
\text { Anova }\end{array}$ & $F=7.906 \mathrm{df}=3 \mathrm{p}=0.000$ & Accepted \\
\hline
\end{tabular}




\section{Conclusion}

Findings in this study provide very important information on the level of food safety knowledge and major knowledge gaps. $90.8 \%$ of participants know that, food hygiene means to remove the illness-causing factors in food however critical knowledge gaps were determined such as handling of frozen foods, hand washing, statements in national legislation, some important and critical food borne diseases and their agents, proper food storage temperatures and some of the important, critical hygiene rules. It is clear that in order to overcome the deficiencies in knowledge of kitchen workers' food safety and hygiene rules and personal hygiene, inservice training must be supported and maintained regularly in accordance with legal regulations. With the results of this study; it was seen that the regular audits and inspections of the food establishments and the trainings related to their fields have great importance in increasing the knowledge level of the kitchen workers. It was determined that the level of knowledge of employees did not differ according to gender. On the other hand; according to the hypothesis that we obtained that there is a difference according to education levels in terms of "Food Safety and Hygiene Rules knowledge". Also, knowledge of the employees was significantly different according to the job position and to the duration of the food handler in a food establishment.

\section{References}

Abdul-Mutalib, N.A., Abdul-Rashid, M.F., Mustaf, S., Amin-Nordin, S., Hamat, R.A., Osman, M. (2012). Knowledge, attitude and practices regarding food hygiene and sanitation of food handlers in Kuala Pilah, Malaysia. Food Control, 27, 289-293.

Al-Shabib, N.A., Mosilhey, S.H., Husain, F.M. (2016). Cross-sectional study on food safety knowledge, attitude and practices of male food handlers employed in restaurants of King Saud University, Saudi Arabia. Food Control, 59, 212-217.

Anonymous (2011). Gıda Hijyeni Yönetmeliği. Sayı: 28145. Türkiye Cumhuriyeti Gıda Tarım ve Hayvancılık Bakanlığı.

Ansari-Lari, M., Soodbakhsh, S., Lakzadeh, L. (2010). Knowledge, attitudes and practices of workers on food hygienic practices in meat processing plants in Fars, Iran. Food Control, 21, 260-263.

Bas, M., Ersun, A.S., Kivanc, G. (2006). The evaluation of food hygiene knowledge, attitudes, and practices of food handlers in food businesses in Turkey. Food Control, 17, 317-322.

Bolton, D.J., Meally, A., Blair, I.S., McDowell, D.A., Cowan, C. (2008). Food safety knowledge of head chefs and catering managers in Ireland. Food Control, 19, 291-300.

Cates, S.C., Muth, M.K., Karns, S.A., Penne, M.A., Stone, C.N., Harrison, J.E., Radke, V.J. (2009). Certified kitchen managers: do they improve restaurant inspection outcomes?. Journal of Food Protection, 72, 384391.

Clayton, D.A., Griyth, C.J., Price, P., Peters, A.C. (2002). Food handlers' beliefs and self-reported practices. International Journal of Environmental Health Research, 12, 25-39.

Codex Alimentarius Commission. (2003). Recommended international code of practice general principles of food hygiene. $C A C / R C P, \operatorname{Rev}, 4,1-1969$.

Çakiroğlu, F.P., Uçar, A. (2008). Employees' perception of hygiene in the catering industry in Ankara (Turkey). Food Control, 19, 9-15.

Dewaal, C.S. (2003). Safe food from a consumer perspective. Food Control, 14, 75-79.

EFSA. \& ECDC. (2015). The European Union summary report on trends and sources of zoonoses, zoonotic agents and food-borne outbreaks in 2013 European Food Safety Authority and European Centre for Disease Prevention and Control. EFSA Journal, 13, 1-162.

European Food Safety Authority (EFSA). (2010). The community summary report on trends and sources of zoonoses, zoonotic agents and food borne outbreaks in the European Union in 2008. EFSA Journal, 8, 1-313.

Garayoa, R., Vitas, A.I., Díez-Leturia, M., García-Jalón, I. (2011). Food safety and the contract catering companies: Food handlers, facilities and HACCP evaluation. Food Control 22, 2006-2012.

Giritlioglu, İ., Batman, O., Tetik, N. (2011). The knowledge and practice of food safety and hygiene of cookery students in Turkey. Food Control, 22, 838-842. 
Gomes-Neves, E., Araújo, A.C., Ramos, E., Cardoso, C.S. (2007). Food handling: Comparative analysis of general knowledge and practice in three relevant groups in Portugal. Food Control, 18, 707-712.

Howells, A.D., Roberts, K.R., Shanklin, C. W., Pilling, V. K., Brannon, L. A. \& Barrett, B. (2008). Restaurant employees' perceptions of barriers to three food safety practices. American Dietetic Association, 108(8), 1345-1349.

Howes, M., Mcewen, S., Griffiths, M., Harris, L. (1996). Food handler certification by home study: Measuring changes in knowledge and behaviour. Dairy, Food and Environmental Sanitation, 16, 737-744.

Lynch, R.A., Elledge, B.L., Griffith, C.C., Boatright, D.J. (2003). A comparison of food safety knowledge among restaurant managers, by source of training and experience, in Oklahoma County, Oklahoma. Journal of Environmental Health, 66, 9-14.

Marais, M., Conradie, N., Labadarios, D. (2007). Small and micro enterprises aspects of knowledge, attitudes and practices of managers and food handlers knowledge of food safety in the proximity of Tygerberg Academic Hospital, Western Cape. South African Journal of Clinical Nutrition, 20(2), 50-61.

McCarthy, M., Brennan, M., Kelly, A.L., Ritson, C., De Boer, M., Thompson, N. (2007). Who is at risk and what do they know? Segmenting a population on their food safety knowledge. Food Quality and Preference, $18,205-217$.

Mortlock, M.P., Peters, A.C., Griffith, C. (1999). Food hygiene and HACCP in the UK food industry, practices, perceptions and attitudes. Journal of Food Protection, 62, 786-792.

Normanno, G., Firinu, A., Virgilio, S., Mula, G., Dambrosio, A., Poggiu, A. (2005). Coagulase-positive staphylococci and Staphylococcus aureus in food products marketed in Italy. International Journal of Food Microbiology, 98, 73-79.

Nørrung, B., Buncic, S. (2008). Microbial safety of meat in the European Union. Meat Science, 78, 14-24.
Park, S.H., Kwak, T.K., Chang, H.J. (2010). Evaluation of the food safety training for food handlers in restaurant operations. Nutrition Research and Practice, 4, 58-68.

Pichler, J., Ziegler, J., Aldrian, U., Allerberger, F. (2014). Evaluating levels of knowledge on food safety among food handlers from restaurants and various catering businesses in Vienna, Austria 2011/2012. Food Control, 35, 33-40.

Sani, N.A., Siow, O.N. (2014). Knowledge, attitudes and practices of food handlers on food safety in food service operations at the University Kebangsaan Malaysia. Food Control, 37, 210-217.

Sanlier, N. (2009). The knowledge and practice of food safety by young and adult consumers. Food Control, 20, 538-542.

Senior, K. (2009). Estimating the global burden of food borne disease. The Lancet Infectious Diseases, 9, 8081.

Sharif, L., Al-Malki, T. (2010). Knowledge, attitude and practice of Taif university students on food poisoning. Food Control, 21, 55-60.

Smigic, N., Djekic, I., Martins, M.L., Rocha, A., Sidiropoulou, N., Kalogianni, E.P. (2016). The level of food safety knowledge in food establishments in three European countries. Food Control, 63, 187-194.

Soon, J.M., Baines, R., Seaman, P. (2012). Meta-analysis of food safety training on hand hygiene knowledge and attitudes among food handlers. Journal of Food Protection, 75, 793-804.

Todd, E.C.D., Greig, J.D., Bartleson, C.A., Michaels, B.S. (2007). Outbreaks where food workers have been implicated in the spread of food borne disease. Part 3. Factors contributing to outbreaks and description of outbreak categories. Journal of Food Protection, 70, 21992217.

Tokuç, B., Ekuklu, G., Berberoglu, U., Bilge, E., Dedeler, H. (2009). Knowledge, attitudes and self-reported practices of food service staff regarding food hygiene in Edirne, Turkey. Food Control, 20, 565-568. 
Walker, E., Pritchard, C., Stephen, F. (2003). Food handlers' hygiene knowledge in small food businesses. Food Control, 14, 339-343. 